\title{
A comparative study of the use of tiger-specific and heterologous microsatellite markers for population genetic studies of the Bengal tiger (Panthera tigris tigris)
}

\author{
Sudhanshu Mishra ${ }^{1,2}$, Reeta Sharma ${ }^{1,3}$, Sujeet Kumar Singh ${ }^{1,4}$, Ashok Kumar Munjal ${ }^{2,5}$ and \\ Surendra Prakash Goyal ${ }^{1 *}$
}

\footnotetext{
${ }^{1}$ Department of Animal Ecology and Conservation Biology, Wildlife Institute of India, P. O. Box \# 18, Chandrabani, Dehradun - 248001, Uttarakhand, India.

${ }^{2}$ Department of Bioscience and Biotechnology, Banasthali University, Banasthali Vidyapith- 304022, Rajasthan, India. ${ }^{3}$ Population and Conservation Genetics Group, Instituto Gulbenkian de Ciência, Rua da Quinta Grande, 6, Apartado 14, 2781-901 Oeiras, Portugal.

${ }^{4}$ Department of Biology, University of Oulu, PO Box 3000, 90014 Oulu, Finland.

${ }^{5}$ Department of Zoology, Indira Gandhi National Tribal University, Amarkantak-484886, Madhya Pradesh, India.
}

Accepted 3 February, 2014

\begin{abstract}
Comparison of genetic diversity indices of heterologous and species-specific microsatellite loci within a species may provide a panel of appropriate markers for genetic studies, but few studies have carried out such comparisons. We examined and compared the genetic characteristics of tiger-specific and heterologous loci in eight captive Bengal tigers. The mean polymorphic information content (PIC) value of the tiger-specific microsatellite loci $(n=15)$ was 0.447 , and the number of alleles was from 2 to 4 per locus. In comparison, the heterologous microsatellite loci $(n=15)$ had a mean PIC value of 0.539 , and the number of alleles per locus was three to five. Our findings indicate that the heterologous markers have a higher frequency $(n=11)$ of polymorphic microsatellite loci and number of alleles per locus compared with tiger-specific loci. We pooled the highly polymorphic $(\mathrm{PIC}>0.5)$ tiger-specific loci $(n=5)$ and heterologous microsatellite loci $(n=11)$ except one and noted a higher mean observed heterozygosity and PIC values of 0.668 and 0.575 , respectively, compared with the heterologous and tiger-specific loci taken alone. Using a locus selection criterion of PIC $>0.5$, we recommend a combined panel of 16 highly polymorphic loci for genetic studies of the wild population of the Bengal tigers and suggest that either a combination of tiger-specific and heterologous microsatellite primers or heterologous primers be used in genetic studies related to the ecology, biology, socio-biology and behavior of Bengal tigers as $>13$ loci are needed in such studies.
\end{abstract}

Key words: Bengal tiger, highly polymorphic, tiger-specific, heterologous, microsatellite loci.

\section{INTRODUCTION}

The tiger (Panthera tigris) once had the widest geographical distribution among cat species, extending from almost $10^{\circ}$ south of the equator (Bali and Java) to beyond $60^{\circ}$ north (the Russian Far East) and through more than $100^{\circ}$ 
of longitude (Mazak, 1996; Nowell and Jackson, 1996). It is not surprising that the tiger exhibited considerable variation in behavior due to adaptation to diverse bioclimatic zones and the different groups of prey species across its geographical range (Pocock, 1929; Brongersma, 1935; Mazak, 1981, 1996). Three of the nine genetically identified subspecies of the tiger have become extinct (Nowell and Jackson, 1996; Luo et al., 2004).

Poaching is a major conservation threat to the species, and there is a need to curtail the global traffic in tiger parts and products (Dinerstein et al., 2007; Goodrich et al., 2008; Walston et al., 2010). Although the geographic distribution of the tiger once extended across Asia from eastern Turkey to the Sea of Okhotsk, its range has been greatly reduced in recent times due to poaching as well as human disturbances that have led to habitat loss and a reduction in the availability of wild prey species throughout its range (Dinerstein and Wikramanayake, 1993; Nowell and Jackson, 1996; Sunquist et al., 1999; Linkie et al., 2006; Sanderson et al., 2006). Now tigers survive only in small pockets spread from India to Vietnam and in Sumatra, China and the Russian Far East (Nowell and Jackson, 1996).

The Bengal tiger (P.t. tigris), the national animal of India, is listed in Schedule I of the Wildlife (Protection) Act, 1972 of India and in Appendix I of the Convention on International Trade in Endangered Species (CITES). It is one of the six extant tiger subspecies found in India, Nepal, Bhutan, Bangladesh and Myanmar (Luo et al., 2004;

http://assets.panda.org/downloads/wwf_tiger_factsheet_2 010_1.pdf). The reported world tiger population has declined and may be as low as 3200 individuals (http://assets.panda.org/downloads/wwf_tiger_factsheet_ 2010_1.pdf). The largest population (1706) is that of the Bengal tiger in India (Jhala et al., 2011).

Reliable methods of studying the population dynamics and its processes are necessary for designing long-term conservation strategies for any species in fragmented and human-dominated landscapes. Large carnivores such as the tiger are difficult to study because they are often wide ranging and have low densities (Boitani et al., 2008; Karanth, 2003) and are territorial, elusive, cryptic and nocturnal in nature (Karanth et al., 2003). It is practically very difficult to estimate numbers of tigers in terms of sex to understand the population dynamics. It is also difficult to track individual tigers to obtain the ecological, biological and genetic information needed to develop conservation strategies.

In view of the recent advances that have taken place in DNA technologies, population genetics has been widely used in research and conservation of both abundant and rare species (Schwartz et al., 2007; Goedbloed et al., 2013; Holbrook et al., 2013). Molecular methods incorporating non-invasive sampling are commonly used in monitoring the populations of carnivores (Taberlet et al., 1999; Piggott and Taylor, 2003; Waits and Paetkau, 2005;
Schwartz et al., 2007; Cullingham et al., 2010; Miotto et al., 2011) and in studying their socio-biology (Langergraber et al., 2013) and behavioral genetics (Langergraber and Vigilant, 2011; Lyke et al., 2013).

Among the different genetic markers used in wildlife studies are microsatellites, or simple sequence repeats (SSRs). These are regions of the genome that are made up of short repeat sequences, consisting of one to six nucleotides (Hancock, 1999; Sawaya et al., 2013), and they are widely used in studies of various organisms because of their high degree of polymorphism and their co-dominant inheritance. One of the limiting factors in the use of these markers is the development of speciesspecific primers (Lopes et al., 2010) to resolve genetic relationships at all levels of the population structure (Jarne and Lagoda, 1996; Hille et al., 2002). Nevertheless, attempts have been made to use these methods for the domestic cat (Felis catus) (Menotti-Raymond et al., 1999), Sumatran tiger (P. t. sumatrae) (Williamson et al., 2002), Asiatic lion (P. leo persica) (Singh et al., 2002), South China tiger (P. t. amoyensis) (Zhang et al., 2006), puma (Puma concolor) (Kurushima et al., 2006) and Bengal tiger (Bhagvatula and Singh, 2006; Sharma et al., 2008) among the Felidae.

The use of species-specific microsatellites is limited by the time and expense involved and the difficulty in isolating these short tandem repeats and their flanking regions from the genomes of the target organisms. An alternative approach to de novo development is exploitation of the available information by cross-species amplifications among a range of phylogenetically related species (Blanquer-Maumont and Crouau-Roy, 1995; Coltman et al., 1996; Pepin et al., 1995; Scribner et al., 1996; Hille et al., 2002). But it is known that the level of information obtained by using heterologous primers differs among species, generally because of a decrease in the number of successfully amplified loci as the genetic distance increases (Francisco et al., 2006). Considering the information obtained by using species-specific loci, heterologous primers may not be ideal choices for estimating genetic diversity indices. Notwithstanding this, the use of heterologous primers has become quite common in genetic studies because it eliminates the need to develop new sets of primers for each species (Engel et al., 1996). Heterologous primers have been used in studies carried out on the Far Eastern leopard ( $P$. pardus orientalis) (Uphyrkina et al., 2002), jaguar ( $P$. onca) (Ruiz-Garcia et al., 2006), snow leopard ( $P$. uncia) (Waits et al., 2007), clouded leopard (Neofelis nebulosa) (Wilting et al., 2007), leopard (P. pardus) (Mondol et al., 2009), Siberian tiger (P. t. altaica) (Alasaad et al., 2011), cheetah (Acinonyx jubatus) (Charruau et al., 2011) and jaguarandi (Puma yagouaroundi) (Holbrook et al., 2013) and provided support to plan effective conservation strategies. Janecka et al. (2008) modified primers for short amplicon originally developed for the domestic cat (Menotti-Raymond et al., 1999) and used them in genetic 
studies they carried out on the snow leopard.

Thus, heterologous microsatellite loci are of use in intra- and inter-population diversity analysis and can potentially be used in identifying individuals. Thus they may be used in a variety of applications, including gene mapping and analysis of family relatedness and paternity (Angers and Bernatchez, 1996; Vigilant et al., 2001; Inoue et al., 2008), whereas species-specific microsatellite loci are very useful and essential for long-term population genetic studies (Lopes et al., 2010) and for understanding genetic fitness. Therefore, in this study, we compare for the first time the genetic characteristics of tiger-specific microsatellite loci $(n=15)$ developed for the Bengal tiger (Sharma et al., 2008) and Sumatran tiger (Williamson et al., 2002) with those of heterologous microsatellite loci (n = 15) developed for the domestic cat (Menotti-Raymond et al., 1999, 2005) and Asiatic lion (Singh et al., 2002) in captive Bengal tigers using high quality DNA samples. Of these 30 loci, seven are different loci that have so far not been used in other studies on the Bengal tiger. We also suggest a combined panel of highly polymorphic tigerspecific and heterologous microsatellite loci for studying different genetic aspects of the wild population of the Bengal tiger.

\section{MATERIALS AND METHODS}

We obtained blood samples from eight captive Bengal tigers in Mahendra Chaudhury Zoological Park, Chhatbir, Mohali, India. Details such as individual tigers' histories and translocation from other zoos are poorly documented in the 'Indian National Studbook for Bengal Tigers, 2011', and hence the geographic origin of these tigers is unknown. Genomic DNA was extracted from the blood samples using Bio Robot EZ1 (QIAGEN, Germany). We selected and amplified 15 tiger-specific loci (12 dinucleotide and three tetranucleotide repeat loci) developed for the Bengal tiger (Sharma et al., 2008) and Sumatran tiger (Williamson et al., 2002) and 15 heterologous loci (eight dinucleotide and seven tetranucleotide repeat loci) developed for the Asiatic lion (Singh et al., 2002) and domestic cat (Menotti-Raymond et al., 1999, 2005). We examined these loci for their size, range and level of polymorphism in the Bengal tiger (Table 1). Polymerase chain reactions (PCR) were carried out in an Applied Biosystems 9700 thermocycler (Applied Biosystems, Germany) in a $10 \mu \mathrm{l}$ reaction mixture containing $1 \times$ PCR ABI Taq gold buffer, $2.0 \mathrm{mM} \mathrm{MgCl}, 0.4 \mathrm{mM}$ dNTP mix, approximately $50 \mathrm{ng}$ of genomic DNA, 4 pmol of forward and reverse primers and $1 \mathrm{U}$ Taq Gold DNA Polymerase (Applied Biosystems). Amplification of all 30 loci was attempted for all samples using amplification conditions described in the literatures. The amplified PCR products were detected on $2 \%$ agarose gel in 1 $\times$ TAE buffer. Amplified products were visualized and scored on an $A B I 3130$ fluorescent detection system using the GeneMapper software package (Applied Biosystems). The quality of the microsatellite data was statistically assessed for genotyping errors due to non-amplified alleles (null alleles), short-allele dominance (largeallele dropout) and mis-scoring of stutter peaks using MicroChecker 2.2.3 (Van Oosterhout et al., 2004). Statistics of the genetic diversity values were generated using GenAlEx 6 (Peakall and Smouse, 2006) and GIMLET (Valiere, 2002). GENEPOP'007(Rousset, 2008) was used to test the deviations from the Hardy-Weinberg equilibrium (HWE) and the linkage disequilibrium
(LD) in the population at each locus. The polymorphic information content (PIC) of the markers was calculated from the allelic frequencies using Cervus (ver. 3.0) (Kalinowski et al., 2007). Since details of individual tigers were not available in the 'Indian National Studbook for Bengal Tigers, 2011', we estimated the Queller and Goodnight relatedness coefficients (Queller and Goodnight, 1989) using GenAlEx 6 (Peakall and Smouse, 2006) to ensure that the selected individuals were not related to each other. The level of relationship among individuals was established using the R-value as suggested by Blouin (2003).

\section{RESULTS AND DISCUSSION}

Different kind of genotyping errors have been reported to be involved in the use of non-invasively collected samples such as scats (Bonin et al., 2004; Pompanon et al., 2005). However, genotyping data can be validated by the use of a known individual's DNA (Gerloff et al., 1995; Launhardt et al., 1998) and a good-quality sample that can be used as a species control DNA (Kohn et al., 1995; Paxinos et al., 1997; Wasser et al., 1997). Therefore, more studies are needed to document the genetic characteristics of microsatellite loci with a good-quality source of DNA. In view of this, we used blood samples ( $\mathrm{n}$ $=8$ ) as a source of high-quality DNA to minimize genotyping errors. Our data analysis using MicroChecker 2.2.3 (Van Oosterhout et al., 2004) clearly revealed the absence of null alleles, large-allele dropout (Wattier et al., 1998) and scoring errors, associated with peak stuttering (Ewen et al., 2000), in genotyping data generated using tiger-specific and heterologous microsatellite loci.

All 15 tiger-specific loci were successfully amplified in the Bengal tiger samples, and the allele size ranged from 112 to $285 \mathrm{bp}$. The average observed $\left(\mathrm{H}_{\mathrm{O}}\right)$ and expected $\left(H_{E}\right)$ heterozygosities for the 15 polymorphic loci were 0.500 and 0.555 , respectively. Ten loci (PttA4, PttE5, PttF4, PttD5, Ptt4a, PttG4, PttF1, PttD6, 6HDZ056 and $6 \mathrm{HDZ170}$ ) had expected heterozygosity levels above 0.500 . The number of alleles per locus in these loci ranged from 2 to 4 (average 2.933), and the mean PIC was 0.447 . The effective number of alleles per locus ranged from 1.385 to 3.000 (average 2.196). Only five microsatellite loci out of 15 tiger-specific loci had PIC values higher than 0.500 , which is considered to be a very informative value in popu-lation genetic analysis (Botstein et al., 1980) (Table 1).

All heterologous loci $(n=15)$ were amplified, and the allele size ranged from 106 to $302 \mathrm{bp}$. The average observed and expected heterozygosities for all 15 loci were 0.624 and 0.630 , respectively. Fourteen loci (F41, F53, F85, F124, Fca008, Fca126, Fca304, Fca441, Fca506, Fca628, Fca740, Fca742, Ple23 and Ple57) had expected heterozygosity levels above 0.500 (Table 1). The number of alleles per locus at the polymorphic loci ( $\mathrm{n}$ $=15$ ) ranged from 3 to 5 (average 3.666), and the mean PIC was 0.539 . The effective number of alleles per locus ranged from 1.588 to 3.447 (average 2.585). Ten 
Table 1. Genetic characteristics of species-specific and heterologous microsatellite loci in eight captive Bengal tigers.

\begin{tabular}{|c|c|c|c|c|c|c|c|c|c|c|c|}
\hline Locus & $\begin{array}{l}\text { Chr. } \\
\text { Asn. }\end{array}$ & $\begin{array}{l}\text { Di- } \\
\text { /tetra }\end{array}$ & $\begin{array}{c}\text { Size range } \\
\text { (bp) }\end{array}$ & $\mathbf{N}$ & $\mathrm{Na}$ & $\mathrm{Ne}$ & $\mathrm{H}_{\mathrm{O}}$ & $\mathrm{H}_{\mathrm{E}}$ & PIC & $F_{\text {IS }}$ & $\begin{array}{l}\text { Loci selected for } \\
\text { panel }(n=16)\end{array}$ \\
\hline \multicolumn{12}{|c|}{ A: Species-specific (tiger-specific) microsatellite loci } \\
\hline $\mathrm{Ptt} 10 \mathrm{H}^{\ddagger}$ & NK & $D$ & $162-164$ & 8 & 2 & 1.385 & 0.375 & 0.325 & 0.258 & -0.166 & - \\
\hline $\mathrm{PttA}^{\ddagger}$ & NK & D & 188-196 & 8 & 2 & 1.670 & 0.125 & 0.458 & 0.337 & 0.740 & - \\
\hline $\mathrm{PttA}^{\ddagger}$ & NK & D & $143-151$ & 7 & 3 & 2.032 & 0.714 & 0.538 & 0.427 & -0.363 & - \\
\hline $\mathrm{PttC}^{\ddagger}$ & NK & $\mathrm{D}$ & $174-176$ & 8 & 2 & 1.800 & 0.625 & 0.458 & 0.337 & -0.400 & - \\
\hline $\mathrm{PttE}^{\ddagger}$ & NK & $\mathrm{D}$ & $182-190$ & 8 & 4 & 2.314 & 0.750 & 0.650 & 0.559 & -0.166 & $\dagger$ \\
\hline $\mathrm{PttF}^{\ddagger}$ & NK & $\mathrm{D}$ & $192-196$ & 8 & 3 & 2.945 & 0.625 & 0.700 & 0.582 & 0.113 & $\dagger$ \\
\hline $\mathrm{PttD}^{\ddagger}$ & NK & $\mathrm{T}$ & $201-213$ & 7 & 4 & 2.510 & 0.286 & 0.571 & 0.483 & 0.520 & - \\
\hline $\mathrm{Ptt}_{4} \mathrm{a}^{\ddagger}$ & NK & $\mathrm{D}$ & $283-285$ & 8 & 4 & 3.000 & 0.625 & 0.725 & 0.624 & 0.146 & $\dagger$ \\
\hline $\mathrm{PttG}_{4}^{\ddagger}$ & NK & $\mathrm{T}$ & $112-120$ & 8 & 3 & 2.418 & 0.500 & 0.575 & 0.447 & 0.138 & - \\
\hline $\mathrm{PttF}^{\ddagger}$ & NK & $\mathrm{D}$ & $129-133$ & 8 & 3 & 2.219 & 0.500 & 0.592 & 0.456 & 0.164 & - \\
\hline $\mathrm{PttD6}^{\ddagger}$ & NK & $D$ & $180-190$ & 8 & 4 & 2.000 & $0.125^{*}$ & 0.575 & 0.483 & 0.794 & - \\
\hline $\mathrm{PttB}^{\ddagger}$ & NK & $\mathrm{T}$ & $241-245$ & 8 & 2 & 1.528 & $0.000^{*}$ & 0.400 & 0.305 & 1.000 & - \\
\hline $\mathrm{PttB}^{\ddagger}$ & NK & $D$ & $139-141$ & 8 & 2 & 1.800 & 0.625 & 0.458 & 0.337 & -0.400 & - \\
\hline $6 \mathrm{HDZ056} 6^{\S}$ & NK & $D$ & $172-176$ & 8 & 3 & 2.656 & 0.750 & 0.625 & 0.520 & -0.191 & $\dagger$ \\
\hline $6 \mathrm{HDZ170}{ }^{\S}$ & NK & $D$ & $216-226$ & 8 & 3 & 2.656 & $0.875^{\star}$ & 0.675 & 0.556 & -0.376 & $\dagger$ \\
\hline Mean & & & & & 2.933 & 2.196 & 0.500 & 0.555 & 0.447 & 0.103 & \\
\hline \multicolumn{12}{|c|}{ B: Heterologous microsatellite loci } \\
\hline $\mathrm{F} 41^{\pi}$ & $\mathrm{D} 2$ & $\mathrm{~T}$ & $170-188$ & 8 & 4 & 2.656 & 0.625 & 0.708 & 0.616 & 0.166 & $\dagger$ \\
\hline F53 & $\mathrm{A} 1$ & $\mathrm{~T}$ & $128-152$ & 8 & 4 & 2.000 & 0.667 & 0.500 & 0.450 & -0.280 & $\dagger$ \\
\hline F85 & B1 & $\mathrm{T}$ & $156-176$ & 8 & 3 & 2.656 & $0.375^{*}$ & 0.658 & 0.544 & 0.340 & $\dagger$ \\
\hline $\mathrm{F} 124^{\pi}$ & $\mathrm{E} 1$ & $\mathrm{~T}$ & $258-286$ & 8 & 4 & 3.306 & 0.625 & 0.750 & 0.644 & 0.102 & $\dagger$ \\
\hline Fca008 & $\mathrm{A} 1$ & $\mathrm{D}$ & $130-134$ & 8 & 3 & 1.906 & 0.625 & 0.542 & 0.428 & -0.111 & - \\
\hline Fca126 & $\mathrm{B} 1$ & $\mathrm{D}$ & $124-150$ & 8 & 4 & 1.820 & 0.625 & 0.525 & 0.458 & -0.176 & - \\
\hline Fca272 & $\mathrm{A} 3$ & $\mathrm{D}$ & $112-122$ & 8 & 3 & 1.588 & 0.500 & 0.433 & 0.371 & -0.142 & - \\
\hline Fca304 & $\mathrm{A} 2$ & $\mathrm{D}$ & $125-141$ & 8 & 3 & 2.656 & 0.750 & 0.633 & 0.511 & -0.191 & $\dagger$ \\
\hline Fca441" & D3 & $T$ & $149-161$ & 8 & 4 & 2.793 & 0.875 & 0.742 & 0.645 & -0.154 & $\dagger$ \\
\hline Fca506" & $\mathrm{F} 2$ & $D$ & $206-220$ & 8 & 3 & 2.842 & 0.625 & 0.692 & 0.575 & 0.030 & $\dagger$ \\
\hline Fca628" & D2/E3 & $\mathrm{D}$ & $106-110$ & 8 & 3 & 2.945 & 0.444 & 0.660 & 0.586 & 0.378 & $\dagger$ \\
\hline Fca740" & $\mathrm{C} 1$ & $\mathrm{~T}$ & $290-302$ & 8 & 4 & 1.820 & 0.625 & 0.525 & 0.458 & -0.176 & - \\
\hline Fca742 & D4 & $\mathrm{T}$ & $150-176$ & 8 & 4 & 2.842 & 0.500 & 0.692 & 0.592 & 0.200 & $\dagger$ \\
\hline $\mathrm{Ple}^{2} 3^{\psi}$ & NK & $\mathrm{D}$ & $152-168$ & 8 & 4 & 2.793 & 0.750 & 0.692 & 0.592 & -0.154 & $\dagger$ \\
\hline Ple57 ${ }^{\Psi}$ & NK & $D$ & $141-155$ & 8 & 5 & 3.447 & 0.750 & 0.708 & 0.618 & -0.037 & $\dagger$ \\
\hline Mean & & & & & 3.666 & 2.585 & 0.624 & 0.630 & 0.539 & -0.013 & \\
\hline
\end{tabular}

'Locus recommended for panel of 16 microsatellite loci. T, Tetranucleotide repeat; $\mathrm{D}$, dinucleotide repeat; $\mathrm{n}$, number of samples; Na, number of alleles; $\mathrm{Ne}$, effective number of alleles; Chr. Asn., chromosomal assignment; NK, not known; $\mathrm{H}_{\mathrm{O}}$, observed heterozygosity; $\mathrm{H}_{\mathrm{E}}$, expected heterozygosity; PIC, polymorphic information content; HW, significance of Hardy-Weinberg test based on 100 permutations ( $\left.{ }^{*} P<0.05\right)$; $F_{I S}$, inbreeding coefficients. ${ }^{\ddagger}$ Sharma et al. (2008); ${ }^{\S}$ Williamson et al. (2002); "Menotti-Raymond et al. (1999, 2005); ${ }^{4}$ Singh et al. (2002).

microsatellite loci out of 15 heterologous loci had PIC values greater than 0.500 and were considered to be valuable for studies related to population genetic analysis (Botstein et al., 1980) (Table 1). These observed differences in genetic diversity indices between the two types of markers may be arising from the heterologous markers (developed for the domestic cat and Asiatic lion) being phylogenetically old markers compared with the phylogenetically young markers (tiger-specific markers developed for the Bengal tiger and Sumatran tiger) as phylogenetically old markers are known to have greater genetic diversity compared with markers that are young in the evolutionary scale.

The sample size is small in the present study, which may affect the HWE analysis. However, the examined captive population was found to be in HWE at all tigerspecific and heterologous microsatellite loci except PttD6, PttB3, 6HDZ170 and F85, which showed significant $(\mathrm{P}<$ 
Table 2. Comparison of genetic diversity parameters of species-specific (tiger-specific) and heterologous microsatellite loci with combined panel of highly polymorphic loci in eight captive Bengal tigers.

\begin{tabular}{lccc}
\hline Mean values & $\begin{array}{c}\text { Species-specific } \\
\text { Loci }(\mathbf{n}=\mathbf{1 5})\end{array}$ & $\begin{array}{c}\text { Heterologous loci } \\
(\mathbf{n}=\mathbf{1 5})\end{array}$ & $\begin{array}{c}\text { Combined panel of highly } \\
\text { Polymorphic loci }(\mathbf{n}=\mathbf{1 6})\end{array}$ \\
\hline $\mathrm{Na}$ & 2.933 & 3.666 & 3.625 \\
$\mathrm{Ne}$ & 2.196 & 2.585 & 2.781 \\
$\mathrm{H}_{\mathrm{O}}$ & 0.500 & 0.624 & 0.668 \\
$\mathrm{H}_{\mathrm{E}}$ & 0.555 & 0.630 & 0.675 \\
$\mathrm{PIC}$ & 0.447 & 0.539 & 0.575 \\
$\mathrm{~F}_{\mathrm{IS}}$ & 0.103 & -0.013 & -0.004 \\
\hline
\end{tabular}

$\mathrm{Na}$, Number of alleles; $\mathrm{Ne}$, effective number of alleles; $\mathrm{H}_{\mathrm{O}}$, observed heterozygosity; $\mathrm{H}_{\mathrm{E}}$, expected heterozygosity; PIC, polymorphic information content; $F_{\mathrm{IS}}$, inbreeding coefficients.

0.05) deviations from the HWE (Table 1). The inbreeding coefficient $\left(F_{I S}\right)$ was calculated using the procedure of Weir and Cockerham (1984), and a heterozygote excess was found at nine heterologous loci (F53, Fca008, Fca126, Fca272, Fca304, Fca441, Fca740, Ple23 and Ple57), in comparison with seven tiger-specific loci (Ptt10H, PttA4, PttC6, PttE5, PttB2, 6HDZ056 and 6HDZ0170) (Table 1). The mean $F_{I S}$ was found to be positive (0.103) with the tiger-specific loci $(n=15)$; in contrast, it was negative $(-0.013)$ with the heterologous loci $(n=15)$ (Table 1). The observed ambiguity in the $F_{I S}$ values of the tiger-specific loci and heterologous loci may be due to the differences in the allele numbers as well the PIC values. Linkage analysis indicates no significant evidence of an LD $(P>0.01)$, demonstrating that each locus may be considered as an independent genetic marker (Rousset, 2008; Chen et al., 2005). This is an important finding because a population is likely to retain polymorphisms in the absence of an LD. The effectiveness of loci selection will be augmented if they are in a coupling LD (Wills and Miller, 1976).

Analysis of the genetic characteristics indicated a larger number of highly polymorphic loci, with a higher PIC value $(>0.500)$ in the heterologous loci $(n=10)$ than in the tiger-specific loci $(n=5)$. It was apparent that the mean number of alleles per locus, effective number of alleles, heterozygosity and PIC values obtained using the heterologous loci were greater than those obtained with tiger-specific loci (Table 1). However, species-specific loci can be very informative genetically as they have been specifically developed for targeted species and may be quite useful in evaluating the genetic fitness because these loci are closer to the species than are the heterologous loci in the evolutionary scale.

The use of more than 13 polymorphic loci is recommended in studies related to molecular ecology for understanding population genetics, behavior, socio-biology, among others (Blouin, 2003). Similarly, Cornuet and Luikart (1996) stated that the statistical power of examining a genetic bottleneck in a wild population increases with the sample size and the number of loci. However, they also emphasize the point that it is more effective to increase the number of loci than it is to increase the sample size. Therefore, we suggest a combined panel of 16 loci, including tiger-specific loci $(n=5)$ and heterologous loci $(n=11)$, having PIC values $>0.500$, except F53, which was also included in the panel although it has a relatively low PIC value (0.450) because it generates a better genotyping profile that is easy to interpret and use for allele scoring. However, at the same time, the use of a greater number of loci may introduce more genotyping errors when using non-invasively collected samples of a low-quality source of DNA (Creel et al., 2003). This problem may be minimized by using the multiple-tube approach (Navidi et al., 1992; Goossens et al., 1998) and two-step multiplex PCR method without compromising with number of loci (Arandjelovic et al., 2009; Chang et al., 2012) needed to understand species biology and ecology.

Interestingly, the mean $F_{I S}$ value with the combined panel of highly polymorphic loci was close to zero ($0.004)$. This indicates that the population of captive tigers $(n=8)$ is in HWE. Hence, the results with the combined panel of selected loci are promising compared with the tiger-specific loci $(n=15)$ and heterologous loci $(n=15)$ alone. The combined panel yields relatively high average values of the heterozygosities $\left(\mathrm{H}_{\mathrm{O}}=0.668\right.$ and $\mathrm{H}_{\mathrm{E}}=$ 0.675). The number of alleles per locus at the polymorphic loci $(n=16)$ ranged from three to five (average 3.625), the effective number of alleles per locus ranged from 2.000 to 3.447 (average 2.781), and the mean PIC was 0.575 (Table 2). Considering the small number of individuals in our study, we support our results by examining the mean values of $\mathrm{H}_{\mathrm{E}}$ and $\mathrm{H}_{\mathrm{O}}(0.675$ and 0.668 , respectively) of the combined panel $(n=16)$, which are comparable with the reported mean values of $\mathrm{H}_{E}$ (0.655 to 0.810$)$ and $H_{0}(0.650$ to 0.7624$)$ in non-invasive genetic studies carried out on the Bengal tiger (Reddy et al., 2012; Gour et al., 2013; Sharma et al., 2013). We established the relatedness among the captive tigers $(n=$ 8) using the combined panel of highly polymorphic loci and estimated the mean value of the relatedness 
coefficient $(R=-0.143)$, which indicated that the selected tigers were not highly related to each other, as is mostly expected in captive individuals.

Our findings clearly indicate that the combined panel of 16 loci, including Bengal tiger- and Sumatran tigerspecific microsatellite loci $(n=5)$ and heterologous loci ( $n$ $=11$ ) that have been developed for the domestic cat and Asiatic lion, will be more useful for genotyping-based studies for evaluating the current range and genetic diversity and for genetic identification and characterization of various geographical populations of wild Bengal tigers from tissue, skin, hair and fecal samples (where more than 13 loci are recommended) (Blouin, 2003), compared with the use of tiger-specific or heterologous primers alone (Table 2).

\section{ACKNOWLEDGMENTS}

We are extremely grateful to Director and Dean, Wildlife Institute of India, Dehradun, India to support and facilitate our study. This work is a part of the WII-Grant-in-Aid project which was supported by Ministry of Environment and Forests, India. We are extremely thankful to Mahendra Chaudhury Zoological Park, Chhatbir, Mohali, India for making blood samples of captive tigers available for this research work. We are thankful to our lab mates and colleagues for their consistant and constructive support throughout the study.

\section{REFERENCES}

Alasaad S, Soriguer RC, Chelomina G, Sushitsky YP, Fickel J (2011). Siberian tiger's recent population bottleneck in the Russian Far East revealed by microsatellite markers. Mamm. Biol. 76:722-726.

Angers B, Bernatchez L (1996). Usefulness of heterologous microsatellites obtained from brook charr, Salvelinus fontinalis Mitchill, in other Salvelinus species. Mol. Ecol. 5:317-319.

Arandjelovic M, Guschanski K, Schubert G, Harris TR, Thalmann O, Siedel H, Vigilant $L$ (2009). Two-step multiplex polymerase chain reaction improves the speed and accuracy of genotyping using DNA from noninvasive and museum samples. Mol. Ecol. Res. 9:28-36.

Bhagvatula J, Singh L (2006). Genotyping fecal samples of Bengal tiger (Panthera tigris tigris) for population estimation: a pilot study. BMC Genet. 7(48):1-12.

Blanquer-Maumont A, Crouau-Roy B (1995). Polymorphism, monomorphism, and sequences in conserved microsatellites in primate species. J. Mol. Evol. 41:492-497.

Blouin MS (2003). DNA-based methods for pedigree reconstruction and kinship analysis in natural populations. Trends Ecol. Evol. 18(10):503-511.

Boitani L, Sinibaldi I, Corsi F, Biase A, D'Inzillo Carranza I, Ravagli M, Reggiani G, Rondinini C, Trapenese P (2008). Distribution of medium- to large-sized African mammals based on habitat suitability models. Biodivers. Conserv. 17:605-621.

Bonin A, Bellemain E, Bronken Eidesen P, Pompanon F, Brochmann C, Taberlet $P$ (2004). How to track and assess genotyping errors in population genetic studies. Mol. Ecol. 13:3261-3273.

Botstein D, White RL, Skolnick M, Davis RW (1980). Construction of a genetic linkage map in man using restriction fragment length polymorphisms. Am. J. Hum. Genet. 32:314-331.

Brongersma LD (1935). Notes on some recent and fossil cats, chiefly from the Malay Archipelago. Zool. Meded. 18:1-89.
Chang Z F, Liu Z J, Yang J Y, Li M, Vigilant L (2012). Noninvasive genetic assessment of the population trend and sex ratio of the Shennongjia population of Sichuan snub-nosed monkeys (Rhinopithecus roxellana). Chin. Sci. Bull. 57:1135-1141.

Charruau P, Fernandes C, Orozco-Terwengel P, Peters J, Hunter L, Ziaie $H$, Jourabchian $A$, Jowkar $H$, Schaller $G$, Ostrowski $S$, Vercammen P, Grange T, Schlotterer C, Kotze A, Geigl EM, Walzer $C$, Burger PA (2011). Phylogeography, genetic structure and population divergence time of cheetahs in Africa and Asia: evidence for long-term geographic isolates. Mol. Ecol. 20:706-724.

Chen YH, Kam YC, Yu HT (2005). Isolation and characterization of polymorphic microsatellite loci for parentage analysis in a rhacophorid tree frog (Chirixalus eiffingeri) with unusual parental care. Mol. Ecol. Notes 5:430-432.

Coltman DW, Bowen WD, Wright JM (1996). PCR primers for harbour seal (Phoca vitulina concolor) microsatellites amplify polymorphic loci in other pinniped species. Mol. Ecol. 5:161-163.

Cornuet JM, Luikart G (1996). Description and power analysis of two tests for detecting recent population bottlenecks from allele frequency data. Genetics 114:2001-2004.

Creel, S., G. Spong,J. L. Sands, J. Rotella, J. Zeigle, L.Joe, PL M. Murphy (2003). Population size estimation in Yellowstone wolves with error-prone noninvasive microsatellite genotypes. Mol. Ecol. 12:2003-2009.

Cullingham C, Curteanu M, Ball MC, Manseau M (2010). Feasibility and recommendations for swift fox fecal DNA profiling. J. Wildl. Manag. 74(4):849-859.

Dinerstein E, Loucks C, Wikramanayake E, Ginsberg J, Sanderson E, Seidensticker J, Forrest J, Bryja G, Heydlauff A, Klenaendorf S, Leimgruber P, Mills J, O'Brien TG, Shrestha M, Simons R, Songer M (2007). The fate of wild tigers. BioScience 57:508-514.

Dinerstein E, Wikramanayake ED (1993). Beyond "hotspots": how to prioritize investments in biodiversity in the Indo-Pacific region. Conserv. Biol. 7: 53-65.

Engel SR, Linn RA, Taylor JF, Davis SK (1996). Conservation of microsatellite loci across species of artiodactyls: implications for population studies. J. Mammal. 77(2): 504-518.

Ewen KR, Bahlo M, Treloar SA, Levinson DF, Mowry B, Barlow JW, Foote SJ (2000). Identification and analysis of error types in high throughput genotyping. Am. J. Hum. Genet. 67(3):727-736.

Francisco FO, Brito RM, Arias MC (2006). Alelle number and heterozygosity for microsatellite loci in different stingless bee species (Hymenoptera, Apidae, Meliponini). Neotrop. Entomol. 35: 638-643.

Gerloff U, Schlotterer C, Rassmann K, Rambold I, Hohmann G, Fruth B, Tautz D (1995). Amplification of hypervariable simple sequence repeats (microsatellites) from excremental DNA of wild living bonobos (Pan paniscus). Mol. Ecol. 4:515-518.

Goedbloed DJ, van Hooft P, Megens H-J, Langenbeck K, Lutz W, Crooijmans RPMA, van Wieren SE, Ydenberg RC, Prins HHT (2013). Reintroductions and genetic introgression from domestic pigs have shaped the genetic population structure of northwest European wild boar. BMC Genet. 14:43.

Goodrich JM, Kerley LL, Smirnov EN, Miquelle DG, McDonald L, Quigley HB, Hornocker MG, McDonald T (2008). Survival rates and causes of mortality of Amur tigers on and near the Sikhote-Alin Biosphere Zapovednik. J. Zool. 276: 323-329.

Goossens B, Waits LP, Taberlet P (1998). Plucked hair samples as a source of DNA: reliability of dinucleotide microsatellite genotyping. Mol. Ecol. 7:1237-1241.

Gour DS, Bhagavatula J, Bhavanishankar M, Reddy PA, Gupta JA et al. (2013). Philopatry and dispersal patterns in tiger (Panthera tigris). PLoS One 8(7): e66956. doi:10.1371/journal.pone.0066956.

Hancock JM (1999). Microsatellites and other simple sequences: genomic context and mutational mechanisms. In: Goldstein DB and Schlötterer C. (eds) Microsatellites: Evolution and Applications. Oxford University Press, New York, pp. 1-9.

Hille A, Janssen IAW, Menken SBJ, Schlegel M, Thorpe RS (2002). Heterologous amplification of microsatellite markers from colubroid snakes in European natricines (Serpentes: Natricinae). J. Hered. 93(1): 63-66.

Holbrook JD, Caso A, DeYoung RW, Tewes ME (2013). Population genetics of jaguarundis in Mexico: implications for future research 
and conservation. Wildl. Soc. Bull. 37(2):336-341.

Inoue E, Inoue-Murayama M, Vigilant L, Takenaka O, Nishida T (2008). Relatedness in wild chimpanzees: influence of paternity, male philopatry, and demographic factors. Am. J. Phys. Anthropol. 137:256-262.

Janecka JE, Jackson R, Yuquang Z, Diqiang L, Munkhtsog B, BuckleyBeason V, Murphy WJ (2008). Population monitoring of snow leopards using noninvasive collection of scat samples: a pilot study. Anim. Conserv. 11:401-411.

Jarne P, Lagoda PJL (1996). Microsatellites, from molecules to populations and back. Trends Ecol. Evol. 11:424-429.

Jhala YV, Qureshi Q, Gopal R, Sinha PR (2011). Status of the Tigers, Co-predators and Prey in India, 2010. National Tiger Conservation Authority, Govt. of India, New Delhi, and Wildlife Institute of India, Dehradun. TR 2011/003, p. 302.

Kalinowski ST, Taper ML, Marshall TC (2007). Revising how the computer program CERVUS accommodates genotyping error increases success in paternity assignment. Mol. Ecol. 16:1099-1106.

Karanth KU (2003). Tiger ecology and conservation in the Indian subcontinent. J. Bombay Nat. Hist. Soc. 100:169-189.

Karanth KU, Nichols JD, Seidensticker J, Dinerstein E, Smith JLD, McDougal C, Johnsingh AJT, Chundawat RS, Thapar V (2003). Science deficiency in conservation practice: the monitoring of tiger populations in India. Anim. Conserv. 6:141-146.

Kohn M, Knauer F, Stoffella A, Schroder W, Paabo S (1995). Conservation genetics ofthe European brown bear: a study using excremental PCR of nuclear and mitochondrial sequences. Mol. Ecol. 4:95-103.

Kurushima JD, Collins JW, Ernest HB (2006). Development of 21 microsatellite loci for puma (Puma concolor) ecology and forensics. Mol. Ecol. Notes 6:1260-1262.

Langergraber KE, Mitani JC, Watts DP, Vigilant L (2013). Male-female socio-spatial relationships and reproduction in wild chimpanzees. Behav. Ecol. Sociobiol. 67:861-873.

Langergraber KE, Vigilant L (2011). Genetic differences cannot be excluded from generating behavioural differences among chimpanzee groups (letter). Proc. R. Soc. B. 278:2094-2095.

Launhardt K, Epplen C, Epplen JT, Winkler P (1998). Amplification of microsatellitesadapted from human systems in faecal DNA of wild Hanuman langurs (Presbytis entellus). Electrophoresis 19:13561361.

Linkie M, Chapron G, Martyr D, Holden J, Leader-Williams N (2006). Assessing the viability of tiger subpopulations in a fragmented landscape. J. Appl. Ecol. 43:576-586.

Lopes DM, Campos LAO, Salomão TMF, Tavares MG (2010). Comparative study on the use of specific and heterologous microsatellite primers in the stingless bees Melipona rufiventris and M. mondury (Hymenoptera, Apidae). Genet. Mol. Biol. 33(2): 390393.

Luo SJ, Kim JH, Johnson WE, Van der Walt J, Martenson J, Yuhki N, Miquelle DG et al. (2004). Phylogeography and genetic ancestry of tigers (Panthera tigris). PLoS Biol. 2:2275-2293.

Lyke MM, Dubach J, Briggs MB (2013). A molecular analysis of African lion (Panthera leo) mating structure and extra-group paternity in Etosha National Park. Mol. Ecol. doi: 10.1111/mec.12279.

Mazak VJ (1981). Panthera tigris. Mamm. Species 152:1-8.

Mazak VJ (1996). Der Tiger. Westarp Wissenschaften, Magdeburg, Heidelberg, Berlin (German), Oxford, ISBN 3894327596.

Menotti-Raymond M, David VA, Lyons LA, Schaffer AA, Tomlin JF, Hutton MK, O'Brien SJ (1999). A genetic linkage map of microsatellites in the domestic cat (Felis catus). Genomics 57:9-23.

Menotti-Raymond M, David VA, Wachter LL, Butler JM, O'Brien SJ (2005). An STR forensic typing system for genetic individualization of domestic cat (Felis catus) samples. J. Forensic Sci. 50:1061-1070.

Miotto RA, Cervini M, Begotti RA, Galetti PM (2011). Monitoring a puma (Puma concolor) population in a fragmented landscape in southeast Brazil. Biotropica 44(1):98-104.

Mondol S, Navya R, Athreya V, Sunagar K, Selvaraj VL, Ramakrishnan $U$ (2009). A panel of microsatellites to individually identify leopards and its application to leopard monitoring in human dominated landscapes. BMC Genet. 10: 79, doi: 10.1186/1471-2156-10-79.

Navidi W, Arnheim N, Waterman MS (1992). A multiple-tubes approach for accurate genotyping of very small DNA samples by using PCR: statistical considerations. Am. J. Hum. Genet. 50:347-359.

Nowell K, Jackson P (1996). Wild Cats: Status Survey and Conservation Action Plan. Gland, Switzerland: IUCN.

Paxinos E, McIntosh C, Ralls K, Fleischer R (1997). A noninvasive method for distinguishing among canid species: amplification and enzyme restriction of DNA from dung. Mol. Ecol. 6:483-486.

Peakall R, Smouse PE (2006). GENALEX6: genetic analysis in Excel. Population genetic software for teaching and research. Mol. Ecol. Notes 6:288-295.

Pepin L, Amigues $\mathrm{Y}$, Lepingle A, Berthier JL, Bensaid A, Vaiman D (1995). Sequence conservation of micro-satellites between Bos taurus (cattle), Capra hircus (goat) and related species: examples of use in the parentage testing and phylogeny analysis. Heredity 74:5361.

Piggott MP, Taylor AC (2003). Remote collection of animal DNA and its applications in conservation management and understanding the population biology of rare and cryptic species. Wildl. Res. 30: 1-13.

Pocock RI (1929). Tigers. J. Bombay Nat. Hist. Soc. 33(3):505-541.

Pompanon F, Bonin A, Bellemain E, Taberlet P (2005). Genotyping errors: causes, consequences and solutions. Nat. Rev. Genet. 6:847859.

Queller DC, Goodnight KF (1989). Estimating relatedness using genetic markers. Evolution 43:258-275.

Reddy PA, Gour DS, Bhavanishankar M, Jaggi K, Hussain SM, Harika K, Shivaji S (2012). Genetic evidence of tiger population structure and migration within an isolated and fragmented landscape in northwest India. PLoS One 7(1): e29827.

Rousset F (2008). GENEPOP'007: a complete re-implementation of the GENEPOP software for Windows and Linux. Mol. Ecol. Resour. 8: 103106.

Ruiz-Garcia M, Payán E, Murillo A, Alvarez D (2006). DNA microsatellite characterization of the jaguar (Panthera onca) in Colombia. Genes Genet. Syst. 81:115-127.

Sanderson E, Forrest J, Loucks C, Ginsberg J, Dinerstein E et al. (2006). Setting Priorities for the Conservation and Recovery of Wild Tigers: 2005-2015, the Technical Assessment, http://www.worldwildlife.org/species/finder/tigers/public ations.html.

Sawaya S, Bagshaw A, Buschiazzo E, Kumar P, Chowdhury S, Black MA, Gemmell N (2013). Microsatellite tandem repeats are abundant in human promoters and are associated with regulatory elements. PLOS One 8(2): e54710.

Schwartz MK, Luikart G, Waples RS (2007). Genetic monitoring as a promising tool for conservation and management. Trends Ecol. Evol. 22:25-33

Scribner KT, Gust JR, Fields RL (1996). Isolation and characterization of novel salmon microsatellite loci: cross-species amplification and population genetic applications. Can. J. Fish. Aquat. Sci. 53:833-841.

Sharma R, Stuckas H, Moll K, Khan I, Bhaskar R, Goyal SP, Tiedemann R (2008). Fourteen new di- and tetranucleotide microsatellite loci for the critically endangered Indian tiger (Panthera tigris tigris). Mol. Ecol. Resour. 8:1480-1482.

Sharma S, Dutta T, Maldonado JE, Wood TC, Panwar HS, Seidensticker J (2013). Forest corridors maintain historical gene flow in a tiger metapopulation in the highlands of central India. Proc. R. Soc. B. 280: 20131506, http://dx.doi.org/10.1098/rspb.2013.1506.

Singh A, Shailaja K, Gaur A, Singh L (2002). Development and characterization of novel microsatellite markers in the Asiatic lion (Panthera leo persica). Mol. Ecol. Notes 2:542-543.

Sunquist M, Karanth KU, Sunquist F (1999). Ecology, behaviour and resilience of the tiger and its conservation needs. In: Seidensticker $\mathrm{J}$, Christie S and Jackson P (eds) Riding the Tiger: Tiger Conservation in Human Dominated Landscapes. Cambridge, Cambridge University Press, pp. 5-18.

Taberlet P, Waits LP, Luikart G (1999). Noninvasive genetic sampling: look before you leap. Trends Ecol. Evol. 14:323-327.

Uphyrkina O, Miquelle D, Quigley H, Driscoll C, O'Brien SJ (2002). Conservation genetics of the Far Eastern leopard (Panthera pardus orientalis). J. Hered. 93(5): 303-311.

Valiere N (2002). GIMLET: a computer program for analysing genetic individual identification data. Mol. Ecol. Notes 2: 377-399.

Van Oosterhout C, Hutchinson WF, Wills DPM, Shipley P (2004). 
MICROCHECKER: software for identifying and correcting genotyping errors in microsatellite data. Mol. Ecol. Notes 4: 535-538.

Vigilant L, Hofreiter M, Siedel H, Boesch C (2001). Paternity and relatedness in wild chimpanzee communities. Proc. Natl. Acad. Sci. USA 98: 12890-12895.

Waits LP, Buckley-Beason VA, Johnson WE, Onoratos D, McCarthy T (2007). A select panel of polymorphic microsatellite loci for individual identification of snow leopards (Panthera uncia). Mol. Ecol. Notes 7:311-314.

Waits LP, Paetkau D (2005). Noninvasive genetic sampling tools for wildlife biologists: a review of applications and recommendations for accurate data collection. J. Wildl. Manag. 69:1419-1433.

Walston J, Robinson JG, Bennett EL, Breitenmoser U, da Fonseca GAB et al. (2010). Bringing the tiger back from the brink: the six percent solution. PLoS Biol. 8(9): e1000485.

Wasser SK, Houston CS, Koehler GM, Cadd GG, Fain SR (1997). Techniques for application of faecal methods to field studies of ursids. Mol. Ecol. 6:1091-1097.

Wattier R, Engel CR, Saumitou-Laprade P, Valero M (1998). Short allele dominance as a source of heterozygote deficiency at

microsatellite loci: experimental evidence at the dinucleotide locus Gv1CT in Gracilaria gracilis (Rhodophyta). Mol. Ecol. 7(11):15691573.

Weir BS, Cockerham CC (1984). Estimating F statistics for the analysis of population structure. Evolution 38: 1358-1370.
Williamson JE, Huebinger RM, Sommer JA, Louis EE, Barber RC (2002). Development and cross amplification of 18 microsatellite markers in the Sumatran tiger (Panthera tigris sumatrae). Mol. Ecol. Notes 2:110-112.

Wills C, Miller C (1976). A computer model allowing maintenance of large amounts of genetic variability in Mendelian populations. 11. The balance of forces between linkage and random assortment. Genetics 82:377-399.

Wilting A, Buckley-Beason VA, Feldhaar H, Gadau J, O'Brien SJ, Linsenmair EK (2007). Clouded leopard phylogeny revisited: support for species recognition and population division between Borneo and Sumatra. Front. Zool. 4(15): doi:10.1186/1742-9994-4-15.

Zhang ZH, Zhang WP, Yue BS, Shen FJ, Zhang L, Hou R, Zhu MY (2006). Twelve polymorphic microsatellite loci for the South China tiger Panthera tigris amoyensis. Mol. Ecol. Notes 6:24-26. 